Jap. J. M. Sc. \& Biol., 16, 217-224, 1963

\title{
STATISTICAL SURVEY OF INTERNAL PARASITES IN CYNOMOLGUS MONKEYS (Macaca irus)
}

From the winter of 1961 to the spring of 1962, necropsies were done on 1,108 cynomolgus monkeys (Macaca irus) in order to determine the percentage occurence of infections by parasitic helminths and internal arthropods.

Up to the present time, no data of infection rates of parasites in cynomolgus monkeys have been published, except for the report of Haberman and Williams (1957) who dealt with 82 cynomolgus monkeys examined for the presence of parasite eggs in fecal samples. Therefore the present report will be of benefit for those who use cynomolgus monkeys as an experimental animal.

\section{Materials and Methods.}

1) The monkeys were obtained from Malaya, Cambodia and the Philippines through four importers. One thousand and one hundred and eight monkeys that were autopsied consisted of 267 animals that died a natural death and 841 ones that were apparently healthy and sacrificed. Most of the former died within 2 to 3 weeks after they were brought to the N. I. H. . The latter animals were killed after they had been used for the safety-test of polio vaccine.

2) Every monkey was thoroughly examined by the naked eye to confirm whether it was infected with any species of parasite or not. Monkeys were classified according to their sex, estimated age, nutritional conditions, habitats and the season in which they were autopsied. Thus the infection rate of each parasite was calculated, and statistical test of significance of percentage difference was carried out at the one percent level of significance by the use of "binominal probability paper" which was issued by the Union of Japanese Scientists and Engineers (Nihon Kagaku-gijutsu Renmei in Japanese name).

3) The methods of care and management of monkeys were the same as those described in Experiment 1 in another paper (1963) published by the present authors.

Results.

\section{1) General Feature.}

As shown in Table 1, 913 monkeys (82.4\%) were infected with one or more species of internal parasite and there was statistically no difference in this general feature of infection rate between naturally deceased animals and sacrificed ones. The name and infection rate of each parasite are shown in Table 2 . The highest rate was $61.6 \%$ of Oesophagostomum species, followed by $28.6 \%$ of Spiruridae, $22.3 \%$ of Gastrodiscoides homonis, $21.8 \%$ of Pneumonyssus sp. and so on. A statistically significant difference between naturally deceased animals and sacrificed ones was found only in the infection rate of both Gastrodiscoides hominis and Nochtia nochti, namely the infection rate of them was higher in the sacrificed cases than in the naturally deceased ones.

\section{2) Infection Rate According to the Sex.}

In almost all species examined, a statistically significant difference of the infection rate according to the sex was not found (see Table 3). For this reason, it may be said that there is no difference in susceptibility of the cynomolgus monkey to these 
Table 1. General feature of infection rate

\begin{tabular}{|c|c|c|c|c|}
\hline \multicolumn{2}{|c|}{ Parasite } & \multicolumn{3}{|c|}{ Host } \\
\hline Infection & No. of species & Died & Sacrificed & Total \\
\hline \multirow{6}{*}{+} & 1 & $108 *(40.4) * *$ & $305(36.3)$ & $413(37.3)$ \\
\hline & 2 & $68(25.5)$ & $202(24.0)$ & $270(24.4)$ \\
\hline & 3 & $29(10.9)$ & $118(14.0)$ & $147(13.2)$ \\
\hline & 4 & $11(4.1)$ & $50(5.9)$ & $61(5.5)$ \\
\hline & 5 or more & $2(0.7)$ & $20(2.4)$ & $22(2.0)$ \\
\hline & Total & $218(81.6)$ & $695(82.6)$ & $913(82.4)$ \\
\hline- & & $49(18.4)$ & $146(17.4)$ & $195(17.6)$ \\
\hline Total & & $267(100.0)$ & $841(100.0)$ & $1108(100.0)$ \\
\hline
\end{tabular}

* No. of parasite positive animals.

** Figure in parenthesis is percentage.

Table 2. Infection rates of various species of parasite

\begin{tabular}{lccc}
\hline \multirow{2}{*}{ Parasite } & \multicolumn{3}{c}{ Host } \\
\cline { 2 - 4 } & \multicolumn{1}{c}{ Died } & Sacrificed & Total \\
\hline Oesophagostomum sp. & $158 / 267^{\#}(59.2)$ & $525 / 841(62.4)$ & $683 / 1108(61.6)$ \\
Spiruridae* & $83 / 267(31.3)$ & $234 / 841(27.8)$ & $317 / 1108(28.6)$ \\
Gastrodiscoides hominis & $37 / 267(13.9)$ & $210 / 841(25.0)$ & $247 / 1108(22.3)$ \\
Pneumonyssus sp. & $59 / 267(22.1)$ & $182 / 841(21.6)$ & $241 / 1108(21.8)$ \\
Small pearl-like nodule** & $17 / 267(6.4)$ & $69 / 841(8.2)$ & $86 / 1108(7.8)$ \\
Nochtia nochti & $5 / 262(1.9)$ & $54 / 841(6.4)$ & $59 / 1108(5.3)$ \\
Trichuris trichiuris & $9 / 267(3.4)$ & $49 / 841(5.8)$ & $58 / 1108(5.2)$ \\
Nymph of Armillifer maniliformis & $7 / 267(2.6)$ & $11 / 841(1.3)$ & $18 / 1108(1.6)$ \\
Enterobius vermicularis & $3 / 267(1.1)$ & $10 / 841(1.2)$ & $13 / 1108(1.2)$ \\
Cestoda & $2 / 267(0.7)$ & $10 / 841(1.2)$ & $12 / 1108(1.1)$ \\
\hline
\end{tabular}

* Physaloptera sp. et Streptopharagus sp.

** This is found on the serous membrane of small intestine and may have something to do with Cestoda infection.

\# Denominator is the number of animals autopsied and numerator is the number of positive animals.

parasites according to sex. However, the infection rate of both nymphs of Armillifer maniliformis and small pearl-like nodule* were higher in female monkeys than in male monkeys.

\section{3) Infection Rates According to the Estimated Ages.}

Table 4 shows the infection rates according to the estimated ages. Age was estimated with inspection of dentition after Hurme \& Wagenen $(1953,1961)$ as well as Spiegel (1934).

* See the explanation in comment of this paper. 
Table 3. Infection rates according to monkeys' sexes

\begin{tabular}{lrrr}
\hline \multirow{2}{*}{ Parasite } & \multicolumn{3}{c}{ Sex } \\
\cline { 2 - 4 } & \multicolumn{1}{c}{ o } & o & Total \\
\hline Oesophagostomum sp. & $400 / 658(60.8)$ & $283 / 450(62.9)$ & $683 / 1108(61.6)$ \\
Spiruridae & $193 / 658(29.3)$ & $124 / 450(27.6)$ & $317 / 1108(28.6)$ \\
Gastrodiscoides hominis & $147 / 658(22.3)$ & $100 / 450(22.2)$ & $247 / 1108(22.3)$ \\
Pneumonyssus sp. & $159 / 658(24.2)$ & $82 / 450(18.2)$ & $241 / 1108(21.8)$ \\
Small pearl-like nodule & $63 / 658(9.6)$ & $23 / 450(5.1)$ & $86 / 1108(7.8)$ \\
Nochtia nochti & $37 / 658(5.6)$ & $22 / 450(5.1)$ & $59 / 1108(5.3)$ \\
Trichuris trichiuris & $43 / 658(6.5)$ & $15 / 450(3.3)$ & $58 / 1108(5.2)$ \\
Nymph of Armillifer maniliformis & $17 / 658(2.6)$ & $1 / 450(0.2)$ & $18(1108(1.6)$ \\
Enterobius vermicularis & $9 / 658(1.4)$ & $4 / 450(0.9)$ & $13 / 1108(1.2)$ \\
Cestoda & $8 / 658(1.2)$ & $4 / 450(0.9)$ & $12 / 1108(1.1)$ \\
\hline
\end{tabular}

Table 4. Infection rates in different ages

\begin{tabular}{|c|c|c|c|c|c|c|c|}
\hline \multirow{2}{*}{ Parasite } & \multicolumn{7}{|c|}{ Age (years)* } \\
\hline & 1 & 2 & 3 & 4 & 5 or more & $\begin{array}{c}\text { Not } \\
\text { estimated }\end{array}$ & Total \\
\hline Oesophagostomum sp. & $\begin{array}{c}3 / 7 \\
(42.9)\end{array}$ & $\begin{array}{c}36 / 59 \\
(61.0)\end{array}$ & $\begin{array}{c}130 / 211 \\
(61.6)\end{array}$ & $\begin{array}{c}103 / 175 \\
(58.9)\end{array}$ & $\begin{array}{c}247 / 393 \\
(62.8)\end{array}$ & $\begin{array}{c}164 / 263 \\
(62.4)\end{array}$ & $\begin{array}{c}683 / 1108 \\
(61.6)\end{array}$ \\
\hline Spiruridae & $\begin{array}{c}1 / 7 \\
(14.3)\end{array}$ & $\begin{array}{l}11 / 59 \\
(18.6)\end{array}$ & $\begin{array}{c}38 / 211 \\
(18.0)\end{array}$ & $\begin{array}{l}51 / 175 \\
(29.1)\end{array}$ & $\begin{array}{c}173 / 393 \\
(44.0)\end{array}$ & $\begin{array}{l}43 / 263 \\
(16.3)\end{array}$ & $\begin{array}{c}317 / 1108 \\
(28.6)\end{array}$ \\
\hline $\begin{array}{l}\text { Gastrodiscoides } \\
\text { hominis }\end{array}$ & $\begin{array}{l}0 / 7 \\
(0.0)\end{array}$ & $\begin{array}{c}8 / 59 \\
(13.6)\end{array}$ & $\begin{array}{l}49 / 211 \\
(23.2)\end{array}$ & $\begin{array}{l}49 / 175 \\
(28.0)\end{array}$ & $\begin{array}{c}104 / 393 \\
(26.5)\end{array}$ & $\begin{array}{c}37 / 263 \\
(14.0)\end{array}$ & $\begin{array}{l}247 / 1108 \\
(22.3)\end{array}$ \\
\hline Pneumonyssus sp. & $\begin{array}{c}1 / 7 \\
(14.3)\end{array}$ & $\begin{array}{l}5 / 59 \\
(8.5)\end{array}$ & $\begin{array}{c}32 / 211 \\
(15.2)\end{array}$ & $\begin{array}{l}32 / 175 \\
(18.3)\end{array}$ & $\begin{array}{c}120 / 393 \\
(30.5)\end{array}$ & $\begin{array}{c}51 / 263 \\
(19.4)\end{array}$ & $\begin{array}{l}241 / 1108 \\
(21.8)\end{array}$ \\
\hline Small pearl-like nodule & $\begin{array}{l}0 / 7 \\
(0.0)\end{array}$ & $\begin{array}{l}3 / 59 \\
(5.1)\end{array}$ & $\begin{array}{l}15 / 211 \\
(7.1)\end{array}$ & $\begin{array}{l}10 / 175 \\
(5.7)\end{array}$ & $\begin{array}{l}42 / 393 \\
(10.7)\end{array}$ & $\begin{array}{c}16 / 263 \\
(6.1)\end{array}$ & $\begin{array}{l}86 / 1108 \\
(7.8)\end{array}$ \\
\hline Nochtia nochti & $\begin{array}{l}0 / 7 \\
(0.0)\end{array}$ & $\begin{array}{c}4 / 59 \\
(6.8)\end{array}$ & $\begin{array}{l}13 / 211 \\
(6.2)\end{array}$ & $\begin{array}{l}10 / 175 \\
(5.7)\end{array}$ & $\begin{array}{c}28 / 393 \\
(7.1)\end{array}$ & $\begin{array}{c}4 / 263 \\
(1.5)\end{array}$ & $\begin{array}{l}59 / 1108 \\
(5.3)\end{array}$ \\
\hline Trichuris trichiuris & $\begin{array}{l}0 / 7 \\
(0.0)\end{array}$ & $\begin{array}{c}0 / 59 \\
(0.0)\end{array}$ & $\begin{array}{c}7 / 211 \\
(3.3)\end{array}$ & $\begin{array}{l}12 / 175 \\
(6.9)\end{array}$ & $\begin{array}{c}22 / 393 \\
(5.6)\end{array}$ & $\begin{array}{l}17 / 263 \\
(6.5)\end{array}$ & $\begin{array}{l}58 / 1108 \\
(5.2)\end{array}$ \\
\hline $\begin{array}{l}\text { Nymph of Armillifer } \\
\text { maniliformis }\end{array}$ & $\begin{array}{l}0 / 7 \\
(0.0)\end{array}$ & $\begin{array}{c}0 / 59 \\
(0.0)\end{array}$ & $\begin{array}{l}3 / 211 \\
(1.4)\end{array}$ & $\begin{array}{c}0 / 175 \\
(0.0)\end{array}$ & $\begin{array}{l}12 / 393 \\
(3.1)\end{array}$ & $\begin{array}{c}3 / 263 \\
(1.1)\end{array}$ & $\begin{array}{l}18 / 1108 \\
(1.6)\end{array}$ \\
\hline Enterobius vermicularis & $\begin{array}{l}0 / 7 \\
(0.0)\end{array}$ & $\begin{array}{c}0 / 59 \\
(0.0)\end{array}$ & $\begin{array}{l}3 / 211 \\
(1.4)\end{array}$ & $\begin{array}{c}2 / 175 \\
(1.1)\end{array}$ & $\begin{array}{c}7 / 393 \\
(1.8)\end{array}$ & $\begin{array}{c}1 / 263 \\
(0.4)\end{array}$ & $\begin{array}{c}13 / 1108 \\
(1.2)\end{array}$ \\
\hline Cestoda & $\begin{array}{c}0 / 7 \\
(0.0)\end{array}$ & $\begin{array}{c}2 / 59 \\
(3.4)\end{array}$ & $\begin{array}{c}6 / 211 \\
(2.8)\end{array}$ & $\begin{array}{c}3 / 175 \\
(1.7)\end{array}$ & $\begin{array}{c}1 / 393 \\
(0.3)\end{array}$ & $\begin{array}{c}0 / 263 \\
(0.0)\end{array}$ & $\begin{array}{c}12 / 1108 \\
(1.1)\end{array}$ \\
\hline
\end{tabular}

* Ages are estimated by dental formula.

Oesophagostomum $s p$. was prevalent ( $42.9 \%$ positive) already in one year-old animals. There was a tendency towards rise of infection rate with increasing ages in Spiruridae, Gastrodiscoides hominis and Pneumonyssus sp., however it seems to be unable to say that this tendency existed also in other species.

4) Infection Rates According to the Nutritional Conditions.

Infection rates according to the nutritional conditions of monkeys are shown in 
Table 5. Gradation of nutritional condition was empirically conducted by general body-inspection and -palpation. Grade "+" means a good condition of nutrition, "士" means an ordinary condition and "-" means a bad one.

As it is well understood from the table, in almost all species of worms examined, no difference of infection rate was found according to the conditions of nutrition. But

Table 5. Infection rates according to the nutritional conditions of monkeys

\begin{tabular}{|c|c|c|c|c|c|}
\hline \multirow{2}{*}{ Parasite } & \multicolumn{5}{|c|}{ Nutrition } \\
\hline & + & \pm & - & Not estimated & Total \\
\hline Oesophagostomum sp. & $\begin{array}{l}91 / 148 \\
(61.5)\end{array}$ & $\begin{array}{c}476 / 751 \\
(63.4)\end{array}$ & $\begin{array}{l}82 / 154 \\
(53.2)\end{array}$ & $\begin{array}{c}34 / 55 \\
(61.8)\end{array}$ & $\begin{array}{l}683 / 1108 \\
(61.6)\end{array}$ \\
\hline Spiruridae & $\begin{array}{c}49 / 148 \\
(33.1)\end{array}$ & $\begin{array}{c}207 / 751 \\
(27.6)\end{array}$ & $\begin{array}{l}54 / 154 \\
(35.1)\end{array}$ & $\begin{array}{c}7 / 55 \\
(12.7)\end{array}$ & $\begin{array}{l}317 / 1108 \\
(28.6)\end{array}$ \\
\hline Gastrodiscoides hominis & $\begin{array}{l}50 / 148 \\
(33.8)\end{array}$ & $\begin{array}{c}169 / 751 \\
(22.0)\end{array}$ & $\begin{array}{l}21 / 154 \\
(15.8)\end{array}$ & $\begin{array}{r}7 / 55) \\
(12.7)\end{array}$ & $\begin{array}{l}247 / 1108 \\
(22.3)\end{array}$ \\
\hline Pneumonyssus sp. & $\begin{array}{c}40 / 148 \\
(27.1)\end{array}$ & $\begin{array}{c}158 / 751 \\
(21.0)\end{array}$ & $\begin{array}{l}39 / 154 \\
(25.3)\end{array}$ & $\begin{array}{r}4 / 55) \\
(7.3)\end{array}$ & $\begin{array}{l}241 / 1108 \\
(21.8)\end{array}$ \\
\hline Small pearl-like nodule & $\begin{array}{c}24 / 148 \\
(16.2)\end{array}$ & $\begin{array}{l}49 / 751 \\
(6.5)\end{array}$ & $\begin{array}{l}11 / 154 \\
(7.1)\end{array}$ & $\begin{array}{c}2 / 55 \\
(3.6)\end{array}$ & $\begin{array}{l}86 / 1108 \\
(7.8)\end{array}$ \\
\hline Nochtia nochti & $\begin{array}{c}8 / 148 \\
(5.8)\end{array}$ & $\begin{array}{c}46 / 751 \\
(6.1)\end{array}$ & $\begin{array}{c}5 / 154 \\
(3.2)\end{array}$ & $\begin{array}{c}0 / 55 \\
(0.0)\end{array}$ & $\begin{array}{l}59 / 1108 \\
(5.3)\end{array}$ \\
\hline Trichuris trichiuris & $\begin{array}{l}12 / 148 \\
(8.8)\end{array}$ & $\begin{array}{l}39 / 751 \\
(5.2)\end{array}$ & $\begin{array}{c}5 / 154 \\
(3.2)\end{array}$ & $\begin{array}{c}2 / 55 \\
(3.6)\end{array}$ & $\begin{array}{l}58 / 1108 \\
(5.2)\end{array}$ \\
\hline $\begin{array}{l}\text { Nymph of Armillifer } \\
\text { maniliformis }\end{array}$ & $\begin{array}{c}2 / 148 \\
(1.2)\end{array}$ & $\begin{array}{c}11 / 751 \\
(1.4)\end{array}$ & $\begin{array}{c}5 / 154 \\
(3.2)\end{array}$ & $\begin{array}{c}0 / 55 \\
(0.0)\end{array}$ & $\begin{array}{l}18 / 1108 \\
(1.6)\end{array}$ \\
\hline Enterobius vermicularis & $\begin{array}{c}0 / 148 \\
(0.0)\end{array}$ & $\begin{array}{l}10 / 751 \\
(1.3)\end{array}$ & $\begin{array}{c}3 / 154 \\
(1.9)\end{array}$ & $\begin{array}{c}0 / 55 \\
(0.0)\end{array}$ & $\begin{array}{l}13 / 1108 \\
(1.2)\end{array}$ \\
\hline Cestoda & $\begin{array}{c}1 / 148 \\
(0.7)\end{array}$ & $\begin{array}{l}10 / 751 \\
(1.3)\end{array}$ & $\begin{array}{c}1 / 154 \\
(0.6)\end{array}$ & $\begin{array}{c}0 / 55 \\
(0.0)\end{array}$ & $\begin{array}{l}12 / 1108 \\
(1.1)\end{array}$ \\
\hline
\end{tabular}

in both Gastrodiscoides hominis and the small pearl-like nodule, animals under good nutritional canditions had a rather higher infection rate than animals under bad nutritional conditions.

\section{5) Infection Rates According to the Habitats.}

Table 6 shows the infection rates according to the habitats. Since monkeys are brought from the nearly fixed habitat according to the import-agencies, habitat of monkey was classified according to four import-agencies. "A" agency deals with monkeys from Malaya, both " $\mathrm{B}$ " and " $\mathrm{C}$ " agencies with those from Cambodia and " $D$ " with ones from the Philippines.

There was no significant difference of infection rate of Oesophagostomum $s p$. among different habitats, while in Spiruridae, Gastrodiscoides hominis, Pneumonyssus sp., the small pearl-like nodule, Nochtia nochti, Trichuris trichiuris and Enterobius vermicularis, significant differences of infection rate were found according to the habitats. For example, the infection rate of Gastrodiscoides hominis, Pneumonyssus sp., the small pearl-like nodule and Trichuris trichiuris was highest in both " $\mathrm{B}$ " and " $\mathrm{C}$ " agencies (namely in monkeys from Cambodia) followed by " $\mathrm{D}$ " agency (from the Philippines). The lowest rate was seen in "A" agency (from Malaya). In Spiruridae and Nochtia nochti, this order was as follows: Cambodia $>$ Malaya $>$ Philippine. At any rate, it 
Table 6. Infection rates in different habitats of monkeys

\begin{tabular}{lccccc}
\hline \multirow{2}{*}{ Parasite } & \multicolumn{5}{c}{ Habitat } \\
\cline { 2 - 6 } & (Malaya) & $\begin{array}{c}\mathrm{B} \\
\text { (Cambodia) }\end{array}$ & $\begin{array}{c}\mathrm{C} \\
\text { (Cambodia) }\end{array}$ & $\begin{array}{c}\mathrm{D} \\
\text { (Philippine) }\end{array}$ & Total \\
\hline Oesophagostomum sp. & $220 / 362$ & $187 / 316$ & $146 / 227$ & $130 / 203$ & $683 / 1108$ \\
& $(60.8)$ & $(59.2)$ & $(64.3)$ & $(64.0)$ & $(61.6)$ \\
Spiruridae & $87 / 362$ & $92 / 316$ & $110 / 227$ & $28 / 203$ & $317 / 1108$ \\
& $(24.0)$ & $(29.1)$ & $(48.5)$ & $(13.8)$ & $(28.6)$ \\
Gastrodiscoides hominis & $7 / 362$ & $127 / 316$ & $93 / 227$ & $20 / 203$ & $247 / 1108$ \\
& $(1.9)$ & $(40.2)$ & $(41.0)$ & $(10.0)$ & $(22.3)$ \\
Pneumonyssus sp. & $25 / 362$ & $93 / 316$ & $79 / 227$ & $44 / 203$ & $241 / 1108$ \\
& $(6.9)$ & $(29.4)$ & $(34.8)$ & $(21.7)$ & $(21.8)$ \\
Small pearl-like nodule & $5 / 362$ & $42 / 316$ & $27 / 227$ & $12 / 203$ & $86 / 1108$ \\
& $(1.4)$ & $(13.3)$ & $(11.9)$ & $(5.9)$ & $(7.8)$ \\
Nochtia nochti & $12 / 362$ & $29 / 316$ & $14 / 227$ & $4 / 203$ & $59 / 1108$ \\
& $(3.4)$ & $(9.2)$ & $(6.2)$ & $(2.0)$ & $(5.3)$ \\
Trichuris trichiuris & $4 / 362$ & $24 / 316$ & $20 / 227$ & $10 / 203$ & $58 / 1108$ \\
& $(1.1)$ & $(7.6)$ & $(8.8)$ & $(4.9)$ & $(5.2)$ \\
Nymph of Armillifer & $6 / 362$ & $7 / 316$ & $3 / 227$ & $2 / 203$ & $18 / 1108$ \\
maniliformis & $(2.2)$ & $(1.7)$ & $(1.3)$ & $(1.0)$ & $(1.6)$ \\
Enterobius vermicularis & $3 / 362$ & $2 / 316$ & $8 / 227$ & $0 / 203$ & $13 / 1108$ \\
& $(0.8)$ & $(0.6)$ & $(3.5)$ & $(0.0)$ & $(1.2)$ \\
Cestoda & $6 / 362$ & $3 / 316$ & $2 / 227$ & $1 / 203$ & $12 / 1108$ \\
& $(1.7)$ & $(0.9)$ & $(0.9)$ & $(0.5)$ & $(1.1)$ \\
\hline
\end{tabular}

can be generally stated that the infection rate with internal parasites examined prevailed mostly in monkeys from Cambodia.

6) Infection Rates According to the Seasons.

Table 7 shows infection rates according to the seasons in which the animals died. (Two hundred and three monkeys imported through " $\mathrm{D}$ " agency were excluded from this table because they were imported only in winter). In the fluctuation of infection rate during the period of this survey, a statistically significant difference was evidently observed. The infection rate of both Oesophagostomum sp. and Spiruridae was the highest in spring and lowest in autumn. The highest infection rate of Gastrodiscoides hominis was observed in summer, while the lowest in spring. Then, the infection rate of both Pneumonyssus sp. and Trichuris trichiuris was the highest in autumn, and both the small pearl-like nodule and the nymph of Armillifer maniliformis had the highest infection rate in winter.

\section{Comment.}

The present figure of the infection rate of Oesophagostomum sp. in cynomolgus monkey is approximately in accordance with that of Bezubik \& Furmaga (1959) in 100 rhesus monkeys. Moreover, according to them, twenty seven heads out of 100 rhesus monkeys were infected with Streptopharagus sp.. This infection rate is almost equall to the present figure $(28.6 \%)$ of infection rate of Spiruridae (Physaloptera sp. and Streptopharagus sp.).

Graham (1960) described for the first time that monkeys from Asia were often 
Table 7. Infection rates in different seasons

\begin{tabular}{lccccc}
\hline \multirow{2}{*}{ Parasite } & \multicolumn{5}{c}{ Season } \\
\cline { 2 - 6 } & Spring & Summer & Autumn & Winter & Total \\
\hline Oesophagostomum sp. & $218 / 275$ & $69 / 132$ & $96 / 250$ & $170 / 248$ & $553 / 905$ \\
& $(79.2)$ & $(52.3)$ & $(38.4)$ & $(68.5)$ & $(61.1)$ \\
Spiruridae & $120 / 275$ & $24 / 132$ & $44 / 250$ & $101 / 248$ & $289 / 905$ \\
& $(43.6)$ & $(18.2)$ & $(17.6)$ & $(40.7)$ & $(31.9)$ \\
Gastrodiscoides hominis & $48 / 275$ & $47 / 132$ & $77 / 250$ & $55 / 248$ & $227 / 905$ \\
& $(17.4)$ & $(35.6)$ & $(30.8)$ & $(22.1)$ & $(25.1)$ \\
Pneumonyssus sp. & $50 / 275$ & $20 / 132$ & $77 / 250$ & $50 / 248$ & $197 / 905$ \\
& $(18.1)$ & $(15.2)$ & $(30.8)$ & $(20.1)$ & $(21.8)$ \\
Small pearl-like nodule & $6 / 275$ & $14 / 132$ & $27 / 250$ & $27 / 248$ & $74 / 905$ \\
& $(2.1)$ & $(10.6)$ & $(10.8)$ & $(14.9)$ & $(8.2)$ \\
Nochtia nochti & $19 / 275$ & $4 / 132$ & $17 / 250$ & $15 / 248$ & $55 / 905$ \\
& $(6.9)$ & $(3.0)$ & $(6.8)$ & $(6.0)$ & $(6.1)$ \\
Trichuris trichiuris & $3 / 275$ & $8 / 132$ & $22 / 250$ & $15 / 248$ & $48 / 905$ \\
& $(1.0)$ & $(6.1)$ & $(8.8)$ & $(6.0)$ & $(5.3)$ \\
Nymph of Armillifer & $6 / 275$ & $1 / 132$ & $0 / 250$ & $9 / 248$ & $16 / 905$ \\
maniliformis & $(2.1)$ & $(0.8)$ & $(0.0)$ & $(3.6)$ & $(1.8)$ \\
Enterobius vermicularis & $6 / 275$ & $1 / 132$ & $1 / 250$ & $5 / 248$ & $13 / 905$ \\
& $(2.1)$ & $(0.8)$ & $(0.4)$ & $(2.0)$ & $(1.4)$ \\
Cestoda & $1 / 275$ & $2 / 132$ & $2 / 250$ & $6 / 248$ & $11 / 905$ \\
& $(0.3)$ & $(1.5)$ & $(0.8)$ & $(2.4)$ & $(1.2)$ \\
\hline
\end{tabular}

infected with Gastrodiscoides hominis. The present result of Gastrodiscoides hominis may be taken as an illustration of Graham's description. In the present observations, monkeys so severely infected with this parasite that the lumen of the caecum and the upper part of the colon was full of worms were often found, nevertheless no special abnormality could be detected in the general condition of the infected hosts.

The infection rate of Nochtia nochti was $5.3 \%$ in the present survey. The whitegrey or pale-scarlet thickening of the protuberant portion was found near the border between the fundus and the pyloric area of the mucous membrane of the stomach in every case which was infected with Nochtia nochti. The surface of the portion was generally rough and as large as the size of the little finger tip. The small and palered nematode, Nochtia nochti existed usually on the surface of the protuberant portion and in comparatively small number. Bonne \& Sandground (1936) also described that six of sixty-eight cynomolgus monkeys $(8.8 \%)$ had conspicuous gastric tumor which was induced by Nochtia nochti.

Graham (1960) stated that the nymph of the wormlike arthropod Armillifer armillatus was found with modest frequency encysted as a benign parasite in the viscera of the rhesus and cynomolgus monkey. The present survey also revealed the similar finding. One and six-tenths percent of the monkeys examined were infected with the nymph of this genus.

In the present survey, miliary white-grey pearl-like nodules were found either scattered or crowded in $7.8 \%$ of the autopsied animals. These nodules were mainly on the serous membrane of the small intestine and sometimes on the surface of the liver and lungs. According to Dr. Hashimoto of the Department of Parasitology of N. I. H., these nodules may have something to do with Cestoda-infection, and now their details 
are being investigated by Dr. Hashimoto. As far as the present survey is concerned, these nodules were more frequently observed in females than in males, and more often under good untritional conditions than under bad ones. In addition, they were found especially often in monkeys from Malaya and in winter.

The present results, which show that no significant difference of infection rate was seen between naturally deceased animals and sacrificed ones in examined parasites except in Gastrodiscoides hominis and Nochtia nochti, may suggest that the infiuence of examined parasites upon the host was not so serious as to cause death. This suggestion may be endorsed by the facts that the infection rate of both Gastrodiscoides hominis and Nochtia nochti was lower in the monkeys that died a natural death than in the sacrificed ones, and that the infection rate of Gastrodiscoides hominis was higher in the animals of good nutritional conditions rather than in those of bad nutritional conditions.

As it is obviously understood from Table 1 , the infection rate with more than 2 species of parasite in the naturally deceased was not significantly different from that in the sacrificed monkeys, the latter being a little higher than the former. With regard to the multiple parasitism, Ruch (1959) stated that apparently, wild monkeys and apes enter into equillibrium with several parasitic species as they do with one. On the basis of the present necropsy findings, the present authors can agree with Ruch's opinion.

\section{Summary.}

From the winter of 1961 to the spring of 1962, the authors autopsied 1,108 cynomolgus monkeys in order to clarify the infection rates of parasitic helminths and internal arthropods. The results obtained were as follows :

1. 913 monkeys $(82.4 \%)$ were infected with one or more species of internal parasite (Table 1).

2. The highest rate was $61.6 \%$ of Oesophagostomum $s p$., which was followed by $28.6 \%$ of Spiruridae, $22.3 \%$ of Gastrodiscoides hominis, $21.8 \%$ of Pneumonyssus sp. and so on (Table 2).

3. In almost all species examined, there was statistically no significant difference of infection rate according to the hosts' sexes, ages and nutritional conditions (Tables 3,4 and 5), while significant differences were observed in the infection rate according to the monkeys' habitats and the seasons in which the animals were autopsied (Tables 6 and 7$)$.

The authors wish to express their hearty thanks to Dr. H. Hashimoto of the Department of Parasitology of the N.I.H. for his helpful identification of parasite species, and to Dr. T. Takizawa of the Institute for Infectious Disease of Tokyo University for his kind advices of statistical treatment of the obtained data.

\section{REFERENCES}

Bezubik, B. \& Furmaga, F. (1959): The helminth parasites in Macacus rhesus. Acta Parasitol. Polonica, 7, 591-598. (Cited from Graham's paper)

BonNe, C. \& SANDGROUND, J. H. (1939): On the production of gastric tumors, bordering on malignancy in Javanese monkeys through the agency of Nochtia nochti, a parasitic nematode. Am. J. Cancer, 37, 173-185.

Graham, G. L. (1960) : Parasitism in monkeys. Ann. N. Y. Acad. Sc., 85, 842-860.

Habermann, R. T. \& Williams, F. P. (1957): Diseases seen at necropsy of 708 Macaca 
mulatta (Rhesus monkey) and Macaca philippinensis (Cynomolgus monkey). Am. J. Vet. Res., 18, 419-426.

Honjo, S., Fujiwara, T., Takasaka, M., Suzuki, Y. \& Imaizumi, K. (1963) : Observations on the diurnal temperature variation of cynomolgus monkey (Macaca irus) and on the effect of changes in the routine lighting upon this variation. Jap. J. M. Sc. \& Biol., 16, 189-199.

Hurme, V. O. \& VAN WAGENEN, G. (1953): Basic data on the emergence of deciduous teeth in the monkey (Macaca mulatta). Proc. Am. Philosoph. Soc., 97, 291-315.

Hurme, V. O. \& VAN Wagenen, G. (1961): Basic data on the emergence of permanent teeth in the rhesus monkey (Macaca mulatta). Ibid., 105, 105-140.

Ruci, T. C. (1959) : Diseases of laboratory primates. Ed. W. B. Saunders Co., p. 193.

SPIEGEL, A. (1934) : Der zeitliche Ablauf der Bezähnung und des Zahnwechsels bei Javamakaken (Macaca irus mordax). Zeitschr. Wiss. Zoologie, 145, 711-732.

Department of Veterinary Science, National Institute of

Health, Tokyo

\author{
SHIGEO HONJO \\ KEN MUTO \\ TOORU FUJIWARA \\ YASUKO SUZUKI \\ KIYOSHI IMAIZUMI
}

Received: May 2nd, 1963 